BMC

Veterinary Research

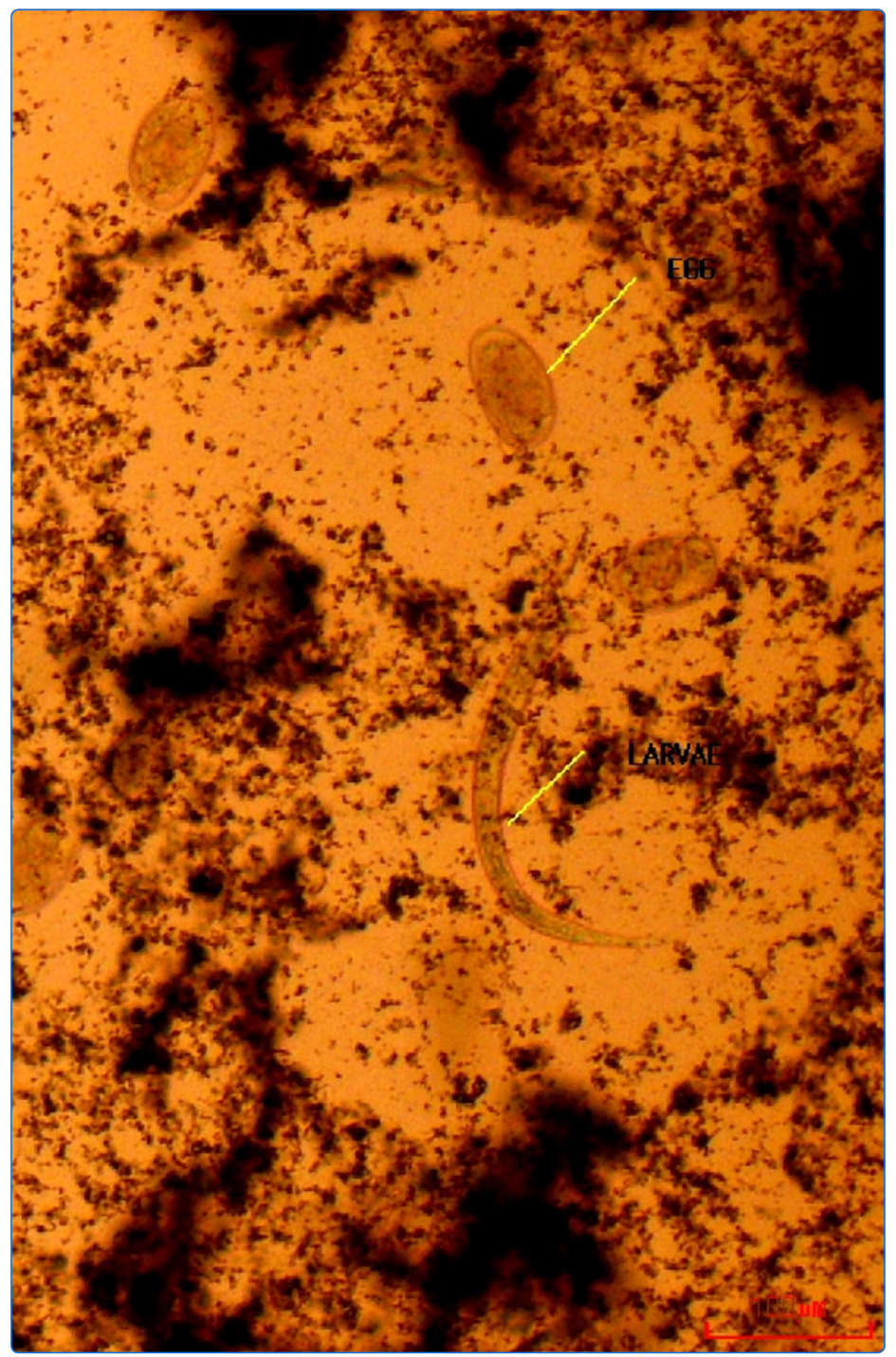

Efficacy and toxicity of thirteen plant leaf acetone extracts used in ethnoveterinary medicine in South Africa on egg hatching and larval development of Haemonchus contortus

Adamu et al.

C Biomed Central 


\title{
Efficacy and toxicity of thirteen plant leaf acetone extracts used in ethnoveterinary medicine in South Africa on egg hatching and larval development of Haemonchus contortus
}

Mathew Adamu ${ }^{1,2}$, Vinasan Naidoo ${ }^{3}$ and Jacobus N Eloff ${ }^{*}$

\begin{abstract}
Background: Helminthiasis is a major limitation to the livestock industry in Africa. Haemonchus contortus is the singular most important helminth responsible for major economic losses in small ruminants. The high cost of anthelmintics to small farmers, resistance to available anthelmintics and residue problems in meat and milk consumed by humans further complicates matters. The use of plants and plant extracts as a possible source of new anthelmintics has received more interest in the last decade. Our aim was not to confirm the traditional use, but rather to determine activity of extracts.

Based on our past experience acetone was used as extractant. Because it is cheaper and more reproducible to evaluate the activity of plant extracts, than doing animal studies, the activity of acetone leaf extracts of thirteen plant species used traditionally in ethnoveterinary medicine in South Africa were determined using the egg hatch assay and the larval development test. Cytotoxicity of these extracts was also evaluated using the MTT cellular assay.

Results: Extracts of three plant species i.e. Heteromorpha trifoliata, Maesa lanceolata and Leucosidea sericea had $\mathrm{EC}_{50}$ values of $0.62 \mathrm{mg} / \mathrm{ml}, 0.72 \mathrm{mg} / \mathrm{ml}$ and $1.08 \mathrm{mg} / \mathrm{ml}$ respectively for the egg hatch assay. Clausena anisata; $(1.08 \mathrm{mg} / \mathrm{ml})$ and Clerodendrum glabrum; $(1.48 \mathrm{mg} / \mathrm{ml})$ extracts were also active. In the larval development assay the $\mathrm{H}$. trifoliata extract was the most effective with an $\mathrm{EC}_{50}$ of $0.64 \mathrm{mg} / \mathrm{ml}$ followed by L. sericea $(1.27 \mathrm{mg} / \mathrm{ml})$. The activities in the larval development test were generally lower in most plant species than the egg hatch assay. Based on the cytotoxicity results $C$. anisata was the least toxic with an $\mathrm{LC}_{50}$ of $0.17 \mathrm{mg} / \mathrm{ml}$, while Cyathea dregei was the most toxic plant with an $\mathrm{LC}_{50}$ of $0.003 \mathrm{mg} / \mathrm{ml}$. The $C$. anisata extract had the best selectivity index with a value of 0.10 and 0.08 for the two assays, followed by $H$. trifoliata and $L$. sericea with values of $0.07,0.07$ and $0.05,0.04$. The $C$. dregei extract had the worst selectivity index with a value of 0.00019 for both assays.
\end{abstract}

Conclusion: The result of this study indicates which species should be further investigated in depth for isolation of compounds.

Keywords: Anthelmintic, Ethnoveterinary, Plant species, Haemonchus contortus, In vitro, Toxicity

\footnotetext{
*Correspondence: kobus.eloff@up.ac.za

${ }^{1}$ Phytomedicine Programme, Department of Paraclinical Sciences, Faculty of

Veterinary Science, University of Pretoria, Pretoria, South Africa

Full list of author information is available at the end of the article
} 


\section{Background}

The parasitic gastroenteritis (PGE) complex is a disease entity caused by helminth parasites belonging to different genera mostly within the class nematoda. Of these, Haemonchus contortus is the single most important constraint to sheep production in South Africa [1] with estimated direct and indirect economic losses of US \$45 million (I.G. Horak personal communication quoted by Waller [2]). Direct losses are due to a drop in production (carcass quality and carcass weight) or death of animals; while indirect losses are due to the costs of drugs, labour and drenching equipment required in control strategies $[3,4]$. The cost of controlling helminth infestation in livestock is also very high globally with chemotherapy remaining the most widely used method of treatment.

Unfortunately the excessive use of these drugs when not necessary, in addition to their use at incorrect doses, has resulted in the wide scale emergence of resistance in this parasite. Resistance of Haemonchus contortus was first reported in South Africa in 1975, in the benzimidazole group of anthelmintics [5], and was soon followed by successive reports of resistance to the different classes of anthelmintics [6-10]. The scope of resistance is of major concern when multi-drug resistance Haemonchus species no longer responded to the five major anthelmintic groups i.e. benzimidazole, ganglion blockers, macrocyclic lactones, cholinesterase inhibitors and the uncouplers of oxidative phosphorylation [11-13].

Unfortunately the situation is not getting any better and may not improve in the near foreseeable future with the result that alternative anthelmintic control options need to be developed [14]. Options tried are vaccine development, which while effective, has been bedevilled by antigenic complexity of the parasites [15]. Biological control through the use of the nematode trapping fungus, Duddingtonia flagrans, although once again effective, is very complicated to use as it is a pasture treatment mechanism [16,17]. Therefore the management of the parasites within the animal through the use of medication seems to be the best option. One avenue in which these new treatment agents may be discovered would be to evaluate plant extracts for their ability to treat helminth infestation [18-20].

With South Africa being rich in plant vascular flora, contributing over $10 \%$ of the world vascular flora species [21], these plants may contain chemicals that could manage resistant Haemonchus species [22]. More importantly in addition to an extract being active, these plants could lead to the discovery of new chemical skeletons that could be further enhanced in the laboratory. The aim of this study was to determine the in vitro activity of extracts of plants that are traditionally used to treat helminthic infections. This would be followed up by the isolation of bioactive compounds from the most active plant extracts.

\section{Methods}

Plant collection

The plants evaluated were selected based on published traditional anthelmintic use of the species in South Africa (Table 1). Leaves of the thirteen plant species were collected in November 2009 at the Pretoria National Botanical Garden where the trees were identified and labelled. Voucher specimens were made and stored in the HGW Schweickert Herbarium of the University of Pretoria. The leaves were subsequently dried at room temperature in a ventilated room, milled to a fine powder in Macsalab Mill (Model 2000 LAB Eriez $^{\circledR}$ ) and stored in closed containers in the dark until used.

\section{Plant extraction}

Plant material (1 g) from each species investigated was separately extracted with $10 \mathrm{ml}$ of acetone, (>99\% technical grade, Merck) in polyester centrifuge tubes. Acetone was selected based on its superiority as extractant based on a number of parameters [32] including that it extracts compounds with a wide range of polarities. Aqueous extracts under the conditions we used, contain only a fraction of the compounds present in acetone extracts [33,34]. We have also found that aqueous plant extracts are prone to fungal growth even when kept in a refrigerator at c. $4^{\circ} \mathrm{C}$ possibly due to the presence of sugars or amino acids in the extracts. Furthermore drying extracts frequently led to serious complications in trying to resolubilize them.

The tube was vigorously shaken for $30 \mathrm{~min}$ on an orbital shaker. Tubes were centrifuged at $4000 \times \mathrm{g}$ for $10 \mathrm{~min}$ and the supernatant was filtered using Whatman No.1 filter paper before being transferred into pre-weighed glass containers. The solvent was removed by evaporation under a stream of air in a fume hood at room temperature to produce the dried extract [35]. The extract was reconstituted in $5 \%$ DMSO and tested in the assays.

\section{Recovery and preparation of eggs}

The helminth eggs were prepared according to the method of the World Association for the Advancement of Veterinary Parasitology (WAAVP) [36] with modification. Eggs used in the study were collected from sheep with a monospecific infection of $H$. contortus. The sheep were housed indoor on concrete floor, fed hay, commercial concentrate pellets and had free access to potable water. The faecal pellets were mashed in a blender to make a relatively liquid suspension (slurry), and filtered through a $400 \mu \mathrm{m}$ mesh sieve to remove coarse debris. Thereafter, the suspension was serially filtered through sieves of pore sizes from 250, 150, 90, $63 \mu \mathrm{m}$, until finally eggs were trapped on the $38 \mu \mathrm{m}$ pore mesh. The material on the $38 \mu \mathrm{m}$ mesh was washed into $50 \mathrm{ml}$ centrifuge tubes, resuspended in a magnesium sulphate solution prepared at a specific gravity of 1.10 . This was then centrifuged at 
Table 1 List of plant species used in the investigation, their traditional uses and references

\begin{tabular}{|c|c|c|c|}
\hline Plant species & Family & Medicinal uses & Reference \\
\hline Brachylaena discolor & Asteraceae (267) & Purgatives against intestinal parasites, anthelmintics for calves, sheep and goats & {$[23-25]$} \\
\hline Zanthoxylum capense & Rutaceae (96) & Gastric and intestinal disorders,anthelmintics, cough, bronchitis,pleurisy & {$[23,25]$} \\
\hline Clerodendrum glabrum & Lamiaceae (403) & Intestinal parasites, coughs, fever, and diabetes & [23-25]. \\
\hline Heteromorpha trifoliata & Apiaceae (491) & Intestinal worms, colic in horses and vermifuge, enemas for abdominal disorders & {$[23,24,26]$} \\
\hline Apodytes dimidiata & Icacinaceae (139) & Enemas for intestinal parasites, purgatives, inflammation of the ear & {$[23,24,26]$} \\
\hline Strychnos mitis & Strychnaceae (73) & Malaria, fevers & {$[27]$} \\
\hline Maesa lanceolata & Maesaceae (615) & Anthelmintics, treatment of wounds and infertility & [24]. \\
\hline Indigofera frutescens & Papilionaceae (675) & Anthelmintics & [24]. \\
\hline Leucosidea sericea & Rosaceae (288) & Treatment of opthalmia, anthelmintics, astringents and vermifuge & {$[24,28]$} \\
\hline Melia azedarach & Meliaceae (702) & Effective anthelmintics, emetic, cathartic and treatment of eczema & {$[24,25,29]$} \\
\hline Clausena anisata & Rutaceae (317) & Anthelmintics, purgatives, rheumatism, fevers and myiasis & {$[30]$.} \\
\hline Cyathea dregei & Cyatheaceae (658) & Anthelmintics & [30]. \\
\hline Milletia grandis & Papilionaceae (704) & Anthelmintics and tranquilizers & {$[24,31]$} \\
\hline
\end{tabular}

(PRU voucher specimen numbers provided after family names).

Only the leaves of these plants species were used in the present study.

$1000 \times \mathrm{g}$ for 10 minutes to separate the eggs from other debris. The resultant supernatant was passed through a $38 \mu \mathrm{m}$ sieve to collect the eggs. The eggs were finally harvested by carefully washing them off the $38 \mu \mathrm{m}$ sieve into a $1 \mathrm{~L}$ conical cylinder with distilled water. The concentration of eggs in an aliquot was counted under a microscope. The egg concentration was subsequently brought to a final concentration of 100 eggs per $0.2 \mathrm{ml}$.

\section{Egg hatch assay (EHA)}

Egg hatch assay (EHA) was a modification of the WAAVP guidelines [36], using the dried plant leaf acetone extract dissolved in 5\% dimethyl sulfoxide (DMSO) and albendazole as the positive control. Briefly, an aqueous egg suspension of ( $0.2 \mathrm{ml}$ containing 100 eggs) was distributed in a 48-flat-bottomed microtitre plate and mixed with $0.2 \mathrm{ml}$ of different concentrations ( 0.78 to $25 \mathrm{mg} / \mathrm{ml}$ ) of each plant extract in 5\% DMSO to give the final tested concentration of 0.39 to $12.5 \mathrm{mg} / \mathrm{ml}$ in $2.5 \%$ DMSO. Albendazole was dissolved in 5\% DMSO in water and evaluated at various concentrations ( 0.008 to $25 \mu \mathrm{g} / \mathrm{ml}$ ). The plates were incubated at $27^{\circ} \mathrm{C}$ for $48 \mathrm{~h}$. After the incubation a drop of Lugol's iodine solution was added to each well and the number of larvae and unhatched eggs were counted. The percentage inhibition of egg hatching was calculated. All experiments were undertaken in triplicate on three separate occasions $(3 \times 3)$. All results were compared with $5 \%$ DMSO as the negative control. In all cases eggs were subjected to $2.5 \%$ DMSO due to mixing with the same volume of aqueous suspension.

\section{Larval development test (LDT)}

The egg suspension (100 eggs in $150 \mu \mathrm{l}$ ) was placed into 48-well plates, with $20 \mu \mathrm{l}$ suspension of lyophilised
Escherichia coli (ATCC 9637) [37], $10 \mu \mathrm{l}$ amphotericin B (Sigma), $20 \mu \mathrm{l}$ nutritive media (comprising $0.1 \mathrm{~g}$ yeast extract in $9 \mathrm{ml}$ normal saline and $1 \mathrm{ml}$ Earle's balanced salt solution) and incubated as above for $48 \mathrm{~h}$. After incubation, $200 \mu \mathrm{l}$ of the test extracts $(0.78$ to $25 \mathrm{mg} / \mathrm{ml}$ ) reconstituted in 5\% DMSO in water and albendazole were added to the wells $(\mathrm{n}=3)$ and further incubated for 5 days. Hereafter, the assay was stopped by addition of one drop of Lugol's iodine solution and the $\mathrm{L}_{1}$ (first stage larvae), $\mathrm{L}_{2}$ (second stage larvae) and $\mathrm{L}_{3}$ (third stage larvae) in each well were counted using an inverted microscope. A percentage inhibition of development to $\mathrm{L}_{3}$ was calculated using the formula adopted from Coles et al. [36] as modified by Ademola and Eloff [38]. All results were compared to $5 \%$ DMSO as the negative control. The larvae were subjected to $2.5 \%$ DMSO because the extract was mixed with the same volume of aqueous larval suspension.

\section{Cytotoxicity assay using MTT}

For the assay Vero monkey kidney cells obtained from a confluent monolayer cells were trypsinised and seeded $\left(0.5 \times 10^{3}\right.$ cells per well $)$ in a 96 well microtitre plate and incubated overnight at $37^{\circ} \mathrm{C}$ in $5 \% 200 \mu \mathrm{l}$ minimal essential medium (MEM, Highveld Biological, South Africa) supplemented with $0.1 \%$ gentamicin $\left(\operatorname{Virbac}^{\mathrm{R}}\right)$ and $5 \%$ foetal calf serum (Adcock-Ingram). After 24 hours the media was replaced with $200 \mu \mathrm{l}$ of the extracts $(1,0.1,0.01$, $0.001 \mathrm{mg} / \mathrm{ml}$ ) and further incubated for 5 days. Viability of cells was determined using the tetrazolium-based colorimetric MTT assay (3-5-dimethyl thiazol-2-yl-2, 5-diphenyl tetrazolium bromide) described by Mosmann [39]. In short the media in each well was removed and replaced with fresh media and $30 \mu \mathrm{l}$ of $5 \mathrm{mg} / \mathrm{ml}$ MTT in 
PBS and subsequently incubated for $4 \mathrm{~h}$. Hereafter the medium was removed and cells washed with PBS, prior to the addition of DMSO $(50 \mu \mathrm{l})$ to dissolve any formazan crystals present. The absorbance of the wells was measured with a Versamax microplate reader at $570 \mathrm{~nm}$ (pathlenght $1 \mathrm{~cm})$. Different concentrations of berberine chloride (Sigma) were used as a positive control, while wells containing only cells without extracts were the negative control. The percentage cell viability relative to the pure growth was calculated. The $\mathrm{LC}_{50}$ values was calculated by determining the concentration of plant extracts resulting in $50 \%$ reduction of absorbance compared to untreated cells. Tests were carried out in triplicate and each experiment was repeated three times.

\section{Data analysis}

The results generated in this study were recorded using Excel for windows 7 . The $\mathrm{EC}_{50}$ and $\mathrm{LC}_{50}$ were calculated in Kinetica 5.0 (Thermo) using a sigmoid inhibitory model. The results are presented in the mean $\mathrm{EC}_{50} / \mathrm{LC}_{50}$ and the standard error of the mean.

\section{Results \\ Yield}

After extraction once with acetone under these conditions different yields expressed as percentage (i.e. mg extracted from $100 \mathrm{mg}$ of dry material) were obtained. The yields obtained were: L. sericea $6.27 \%$, A. dimidiata $6.07 \%$, Z. capense $(0.81 \%)$, B. discolor $(3.30 \%)$, C. glabrum (1.60\%), H. trifoliata (1.28\%), S. mitis (3.75\%), M. lanceolata (2.79\%), I. frutescens (2.05\%), M. azedarach (2.29\%), C. anisata (3.40\%), C. dregei (2.50\%) and $M$. grandis (1.24\%).

\section{Egg hatch assay}

The percentage egg hatch inhibition had a dose related response as the concentration increased (Figure 1). At the $12.5 \mathrm{mg} / \mathrm{ml}$ concentration, all the plants extracts except those from Brachylaena discolor, Clerodendrum glabrum, Strychnos mitis and Zanthoxylum capense inhibited egg hatching by $100 \%$. Extracts of three plant species (Heteromorpha trifoliata, Leucosidea sericea and Maesa lanceolata) led to $100 \%$ inhibition at concentrations as low as $3.13 \mathrm{mg} / \mathrm{ml}$. H. trifoliata had the best inhibitory activity at $0.39 \mathrm{mg} / \mathrm{ml}$ with $36.3 \%$ inhibition. The $H$. trifoliata extract had the best $\mathrm{EC}_{50}$ with a value of $0.62 \mathrm{mg} / \mathrm{ml}$ (Table 2), followed by M. lanceolata with an $\mathrm{EC}_{50}$ of $0.72 \mathrm{mg} / \mathrm{ml}$. Extracts of $C$. anisata, $C$. glabrum, A. dimidiata, B. discolor, $M$. grandis and $Z$. capense had a moderate egg hatch activity with $\mathrm{EC}_{50}$ values ranging between $1.48-5.70 \mathrm{mg} / \mathrm{ml}$. The plant extracts with the lowest activity were from $C$. dregei and $S$. mitis with $\mathrm{EC}_{50}$ of $17.64 \mathrm{mg} / \mathrm{ml}$ and $16.56 \mathrm{mg} / \mathrm{ml}$ respectively.

\section{Larval development test}

Similar to the egg hatch assay, the larval development assay had a linear dose related inhibitory response (Figure 2). At concentrations of $12.5 \mathrm{mg} / \mathrm{ml}$ extracts of 8 of the 13 plant species led to complete inhibition, while extracts from five plants (Brachylaena discolor, Clerodendrum glabrum, Cyathea dregei, Strychnos mitis and Zanthoxylum capense) had an activity less than 100\%. For H. trifoliata, L. sericea and M. lanceolata extracts, $100 \%$ inhibition was still evident at 6.25 and $3.13 \mathrm{mg} / \mathrm{ml}$. At the lowest concentration tested $(0.39 \mathrm{mg} / \mathrm{ml}) \mathrm{H}$. trifoliata again had the highest activity with $31 \%$ inhibition. The $\mathrm{EC}_{50}$ of all thirteen plants acetone extracts are presented in Table 2. The $\mathrm{EC}_{50}$ of $H$. trifoliata was the best at $0.64 \mathrm{mg} / \mathrm{ml}$, followed by $L$. sericea and $M$. lanceolata with 1.27 and $1.68 \mathrm{mg} / \mathrm{ml}$ respectively. Both $C$. dregei and $B$. discolor were rather ineffective with the $\mathrm{EC}_{50}$ values of 17.93 and $17.23 \mathrm{mg} / \mathrm{ml}$ respectively.

\section{Cytotoxicity}

The results for the cytotoxicity using the MTT assay are shown in Table 2. Clausena anisata had the highest $\mathrm{LC}_{50}$ (lowest toxicity) of $0.17 \mathrm{mg} / \mathrm{ml}$, followed by Melia azedarach at $0.14 \mathrm{mg} / \mathrm{ml}$. C. dregei was highly toxic with an $\mathrm{LC}_{50}$ of $0.003 \mathrm{mg} / \mathrm{ml}$. Some plant extracts were more toxic to the cells than to the helminth indicating that it would probably not be useful in treating animals. This can be expressed by calculating the selectivity index (SI) of the plant species based on both assays. The selectivity index is calculated by dividing the cytotoxicity $\mathrm{LC}_{50}$ to the $\mathrm{EC}_{50}$ of the assay. The higher the value of the selectivity index the safer the extract is. This value helps to eliminate activity that may possibly be due to a general metabolic toxin. The $C$. anisata extract was the best for both assays; this was followed by $H$. trifoliata and $L$. sericea for both assays and plant species respectively. The plant species with the worst selectivity index was $C$. dregei for both assays.

\section{Discussion}

The main objective of this study was to establish the inhibitory activity of leaf acetone extracts of the 13 plant species traditionally used for their ability to influence the egg hatching and larval development of Haemonchus contortus. Acetone was selected as a suitable extractant due to its ability to extract compounds of a wide polarity range, its miscible with organic and aqueous solvents and is non-toxic to bacteria and fungi organisms [32]. Acetone is a better extractant for plant secondary compounds than water the common solvent used by rural communities. Because a different extractant was used, these results do not necessarily confirm or dispute the traditional use of plant material by rural pastoralists, as compounds of intermediate polarity may be released by microbial or photooxidation processes after extraction. In addition when 


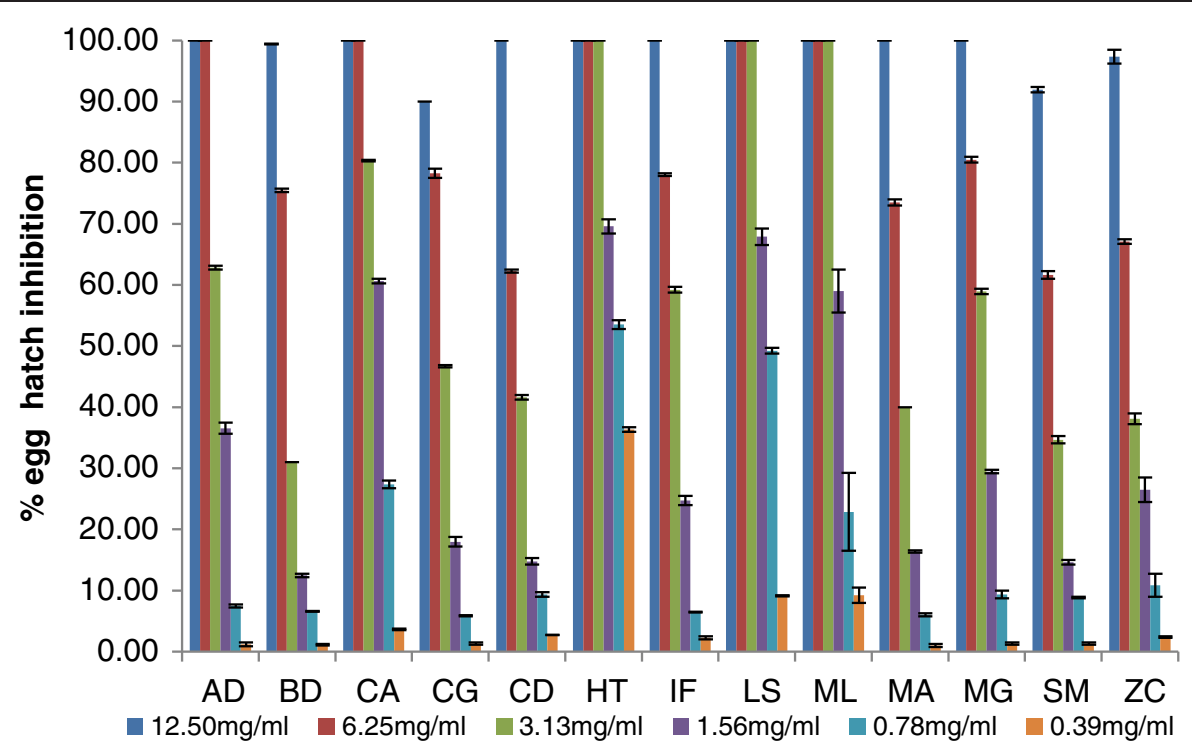

Figure 1 Percentage egg hatch inhibition (mean $\pm \mathrm{SE}$ ) of different concentration of acetone leaf extracts from 13 plant species $(A D ; A$. dimidiata; BD;B. discolor, CA; C. anisata, CG; C. glabrum, CD; C. dregei, HT; H. trifoliata, IF; I. frutescens, LS; L. sericea, ML; M. lanceolata, MA; M. azedarach, MG; M. grandis, SM; S. mitis, ZC; Z. capense). Albendazole was the positive control leading to $100 \%$ inhibition even at the lowest concentration $(0.008 \mathrm{\mu g} / \mathrm{ml})$ used. The negative control DMSO led to $<10 \%$ inhibition.

leaves are fed or particulate material is ingested, it is usually the intermediate to lipid soluble compounds that become bioavailable due to the influence of bile salts or the gastrointestinal tract mucosal barrier preventing the absorption of water soluble compounds [40].

For the evaluation of the results we propose that extracts with $\mathrm{EC}_{50}$ above $6 \mathrm{mg} / \mathrm{ml}$ should be considered to have weak anthelmintic activity as it may be difficult to achieve such high concentration in vivo. When this criterion is applied to the results, the EHA indicate $H$. trifoliata, L. sericea and M. lanceolata, with $\mathrm{EC}_{50 \mathrm{~s}}$ from $0.62-1.08 \mathrm{mg} / \mathrm{ml}$ as potential candidates for further isolation work. These extracts also recorded $100 \%$ egg hatch inhibition within the highest concentrations of $12.5,6.25$ and $3.13 \mathrm{mg} / \mathrm{ml}$. While the actives are unknown at this stage, the activity recorded in this study may be attributed to secondary metabolites [41]. The activity shown by $M$. lanceolata in the present study agrees with earlier work that evaluated the anthelmintic property of various parts of this plant on $H$. contortus from Asia [42]. This activity

Table 2 EC $_{50}$ for Egg Hatch assay (EHA) and Larval Development test (LDT) with their corresponding cytotoxicity values and selectivity index $(\mathrm{SI})$ for thirteen plant species

\begin{tabular}{|c|c|c|c|c|c|}
\hline Names of plants & $\mathrm{EHA} \mathrm{EC}_{50} \pm \mathrm{SE}$ & LDT $\mathrm{EC}_{50} \pm \mathrm{SE}$ & $\mathrm{LC}_{50}$ & SI EHA & SI LDT \\
\hline Apodytes dimidiata & $5.70 \pm 0.23$ & $4.13 \pm 0.56$ & 0.00396 & 0.000695 & 0.00096 \\
\hline Brachylaena discolor & $3.55 \pm 0.27$ & $17.23 \pm 5.47$ & 0.00752 & 0.00212 & 0.00044 \\
\hline Clausena anisata & $1.80 \pm 0.09$ & $2.07 \pm 0.15$ & 0.17186 & 0.09548 & 0.08302 \\
\hline Clerodendrum glabrum & $1.48 \pm 0.07$ & $12.97 \pm 2.33$ & 0.04251 & 0.02872 & 0.00328 \\
\hline Cyathea dregei & $17.64 \pm 4.65$ & $17.93 \pm 6.66$ & 0.00332 & 0.00019 & 0.00019 \\
\hline Heteromorpha trifoliata & $0.62 \pm 0.02$ & $0.64 \pm 0.10$ & 0.04252 & 0.06858 & 0.06644 \\
\hline Indigofera frutescens & $7.11 \pm 1.10$ & $7.58 \pm 1.05$ & 0.1044 & 0.01468 & 0.01377 \\
\hline Leucosidea sericea & $1.08 \pm 0.11$ & $1.27 \pm 0.07$ & 0.0515 & 0.04769 & 0.04055 \\
\hline Maesa lanceolata & $0.72 \pm 0.05$ & $1.68 \pm 0.10$ & 0.01577 & 0.0219 & 0.00939 \\
\hline Melia azedarach & $6.24 \pm 0.20$ & $10.96 \pm 1.79$ & 0.14466 & 0.02318 & 0.0137 \\
\hline Milletia grandis & $5.57 \pm 0.33$ & $6.11 \pm 1.04$ & 0.05336 & 0.00958 & 0.00873 \\
\hline Strychnos mitis & $16.56 \pm 4.88$ & $16.94 \pm 4.71$ & 0.01721 & 0.00104 & 0.00102 \\
\hline Zanthoxylum capense & $13.26 \pm 0.24$ & $13.64 \pm 3.44$ & 0.02095 & 0.00643 & 0.00153 \\
\hline
\end{tabular}

Note: all values for EHA, LDT and $\mathrm{LC}_{50}$ in $\mathrm{mg} / \mathrm{ml}$; Albendazole was positive control and recorded $100 \%$ inhibition at all concentrations ( 0.008 to $25 \mu \mathrm{g} / \mathrm{ml}$ ) used while $2.5 \%$ DMSO recorded $<10 \%$ inhibition. 


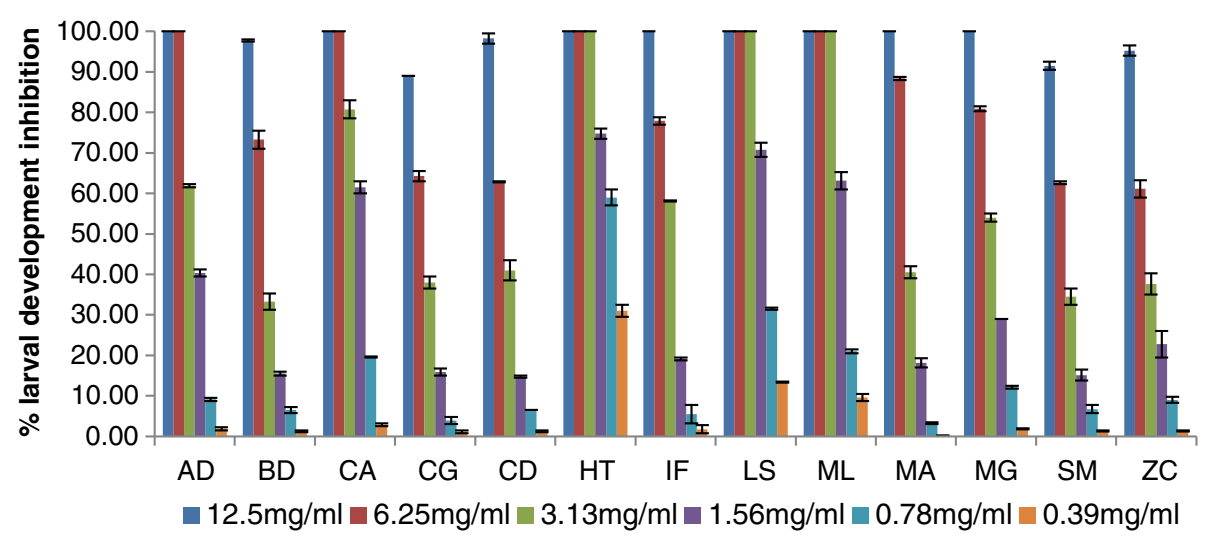

Figure 2 Percentage larval development inhibition (mean $\pm \mathrm{SE}$ ) of different concentration of acetone leaf extracts from 13 plant species (AD; A. dimidiata; BD; B. discolor, CA; C. anisata, CG; C. glabrum, CD; C. dregei, HT; H. trifoliata, IF; I. frutescens, LS; L. sericea, ML; M. lanceolata, MA; M. azedarach, MG; M. grandis, SM; S. mitis, ZC; Z. capense). Albendazole was the positive control leading to $100 \%$ inhibition even at the lowest concentration $(0.008 \mu \mathrm{g} / \mathrm{ml})$ used. The negative control $2.5 \%$ DMSO led to $<10 \%$ inhibition.

may be due to presence of saponins in the leaf of the plant [43]. Saponins are known to destabilize cell membranes hence increase cell permeability by combining with membranes associated sterols [44].

Leucosidea sericea extracts had a reasonably good $\mathrm{EC}_{50}$ value $(1.08 \mathrm{mg} / \mathrm{ml})$ in the current study, thus agreeing with a recent study by Aremu et al. [45] who reported a minimum lethal concentration of $0.52 \mathrm{mg} / \mathrm{ml}$ for the petroleum ether leaf extract using Caenorhabditis elegans. The difference in $\mathrm{EC}_{50}$ values may be attributed to the differences in susceptibility between the non-pathogenic free living $C$. elegans used in their study compared to the pathogenic $H$. contortus we used. The activity of the extract of $L$. sericea may be due to aspidinol [46], condensed tannins or alkaloids [45]. Condensed tannins have anthelmintic activity with varied possible mechanism of actions [47] most especially its astringent property. This is the first report of good anthelmintic activity of Heteromorpha trifoliata and it may be associated with compounds such as fulcarindiol and sarison [48] with antifungal activity from the leaves of this plant. This plant has been used as a vermifuge in horses, by the Xhosa people of South Africa.

The larval development inhibition test yielded similar results to the EHA, H. trifoliata, L. sericea and $M$. lanceolata, once again had excellent activity. Most plants extracts had weak activity with $\mathrm{EC}_{50}$ of $7 \mathrm{mg} / \mathrm{ml}$ and above. The activity of $M$. lanceolata extract confirms activity by Tadesse et al. [42] on the same species from a different origin (Ethiopia). The plants extracts generally had better inhibition activity on the eggs than on the larva of $H$. contortus based on the $\mathrm{EC}_{50}$ values recorded. This is contrary to report by Ademola and Eloff [22] where they had better activity for the larval inhibition compared to the egg hatch assay. The result of this study may be significant as the inhibition of egg hatch is possibly an important method of reducing pasture contamination by the animals during grazing helping in the overall helminth control programme.

In comparison to work undertaken using extracts of other plant species, the activity shown by the three plants with the best activity were in the same order of activities found by Bizimenyera et al., [49] using Peltophorum africanum leaf, bark and roots as well as extracts of Coriandum sativum on eggs and larval development of $H$. contortus [50]. Bizimenyera et al., [49] recorded an $\mathrm{EC}_{50}$ of $0.62 \mathrm{mg} / \mathrm{ml}$ and $0.72 \mathrm{mg} / \mathrm{ml}$ for the leaf acetone extract for the EHA and LDT assays respectively. This is in the same order with values of 0.62 and $0.64 \mathrm{mg} / \mathrm{ml}$ recorded in the EHA and LDT for $H$. trifoliata in the current study. The $\mathrm{EC}_{50}$ of $H$. trifoliata was lower than the acetone leaf extracts of Combretum molle $0.87 \mathrm{mg} / \mathrm{ml}$ and $0.60 \mathrm{mg} / \mathrm{ml}$ for the EHA and LDT respectively [22]. The weak activity recorded by $M$. azedarach $\left(\mathrm{EC}_{50}=10.96 \mathrm{mg} / \mathrm{ml}\right)$ agrees with Maciel et al., [51] in Brazil were they reported an $\mathrm{LC}_{50}$ of $9.18 \mathrm{mg} / \mathrm{ml}$ with the leaf ethanol extract of the plant. It is encouraging that despite the difference in geographical location and organic extractants used, similar bioactivity was obtained for related species.

While the activity from this study show the potential value of plant extracts in the management of haemonchosis. The results need to be interpreted with caution as in vitro activity may not automatically translate into in vivo efficacy. Factors that still need to be considered are animal factors such as absorption and presystemic elimination [52]. More importantly the potential toxicity of the molecule needs to be considered. For this study we used renal cells in culture as an indicator of toxicity. The cells were specifically selected as the kidney is one of the main sites of excretion in animals due to the preferential blood supply of the kidney in addition to their 
high metabolic capacity. The results of the cytotoxicity study were disappointing as in all cases the extracts were toxic to the cells.

However the presence of cellular toxicity is not conclusive as several factors interplay with toxicity results. In this case, it is possible that the use of an organic extractant may have led to extraction of toxic compounds. For this chemical fractionation and isolation may help separate out the potential toxic compounds. It is also possible that in vivo interaction with microsomal and non-microsomal pathways may render the molecule less toxic due to metabolism or simply gut-barrier exclusion may play a role. As a result it is suggested that the three most efficacious plants, which had lower toxicity profiles, be evaluated for further study by fractionation and possibly using a dedicated animal model.

Our experience was that aqueous extracts contained few compounds, had very low biological activity $[33,34]$ and had low or negligible anthelmintic activity $[49,53]$. Many other authors have also used organic extracts in evaluating anthelmintic activity $[20,38,49]$. The way some traditional healers use water extracts by storing it for some time may lead to the solubilisation of intermediate polarity compounds by microbial action or photo-oxidation of compounds in the extract. The aqueous extraction carried out in the laboratory does not approximate the traditionally used methods. In work that was completed after this study had started, members in our group decided to use laboratory aqueous extraction conditions on a plant with excellent antifungal activities [54]. To our surprise the aqueous extract of Markhamia obtusifolia had double the activity of the acetone extract and it was slightly less toxic to Vero kidney cells than to Haemonchus contortus [54]. These results indicate that we should determine the anthelminthic activity of aqueous extracts of plant species that we have already investigated.

In future studies water extracts should therefore also be evaluated for activity and safety. Our policy to date was to extract at room temperature to limit possible changes in the metabolites at high temperatures. To get closer to the conditions used traditionally boiling water extracts and storing under different conditions should also be investigated.

There is also the possibility of using the plant material in the feed directly to control helminths. In an experiment to feed Cereus jamacara an invasive plant species grazed by game and used by a commercial farmer to control helminths had only partial success in decreasing helminth load [55].

\section{Conclusion}

Although direct comparisons may be difficult because traditional healers mainly use water as an extractant it does appear as if several of these traditionally used plants are active against Haemonchus infections. Although the activity of all extracts was several orders of magnitude lower than that of the positive control, high concentrations may be attainable in the animal gut if there are no toxicity problems. It is useful to determine the in vivo toxicity of promising extracts to determine if cellular toxicity is a good indicator of in vivo toxicity. The most promising plants extracts for further study are M. lanceolata, $L$. sericea and $H$. trifoliata. Because substantial work has been done on $M$. lanceolata we have fractionated the extracts of L.sericea and have isolated bioactive compounds and tested their activity in vitro. In vivo animal study will also be evaluated using the acetone extracts of L. sericea in a sheep model.

\section{Competing interests}

There are no conflicts of interest.

\section{Authors' contributions}

MA participated in the design of the study, carried out field work, prepared the extracts, participated in all assay, analysed the data and wrote first draft and subsequent drafts of the manuscript. VN participated in the design and coordination of the study, supervised the study, analysed the data and revised the draft manuscript. JNE participated in the design and coordination of the study, supervised the study and revised the manuscript. All authors read and approved the final manuscript.

\section{Acknowledgements}

The National Research Foundation and University of Pretoria provided funds, the Pretoria National Botanic gardens allowed us to collect plant material. The study of one of us (MA) was made possible by the University of Agriculture Makurdi and Tertiary Education Tax Fund (TETFund), Nigeria.

\section{Author details}

${ }^{1}$ Phytomedicine Programme, Department of Paraclinical Sciences, Faculty of Veterinary Science, University of Pretoria, Pretoria, South Africa. ${ }^{2}$ Department of Veterinary Parasitology and Entomology College of Veterinary Medicine, University of Agriculture Makurdi, Makurdi, Nigeria. ${ }^{3}$ UPBRC, Faculty of Veterinary Science, University of Pretoria, Pretoria, South Africa.

Received: 19 July 2012 Accepted: 21 February 2013

Published: 26 February 2013

\section{References}

1. Vatta AF, Letty BA, Van der Linde MJ, Van Wijk EF, Hansen JW, Krecek RC: Testing for clinical anaemia caused by Haemonchus spp. in goats farmed under resource poor conditions in South Africa using an eye colour chart developed for sheep. Vet Parasitol 2001, 99:1-14

2. Waller PJ: From discovering to development. Current industry perspectives for the development of novel methods of helminth control in livestock. Vet Parasitol 2006, 139:1-14.

3. Soulsby EJL: Helminths. Balliere Tindall, London: Arthropods and Protozoa of Domesticated Animals; 1986.

4. Kassai T: Veterinary Helminthology. Oxford UK: Reed Educational and professional publishers; 1999.

5. Berger J: The resistance of a field strain of Haemonchus contortus to five benzimidazole anthelmintics in current use. J S Afr Vet Assoc 1975, 46:369-372.

6. Van Wyk JA, Gerber HM: A field strain of Haemonchus contortus showing slight resistance to rafoxanide. Onderstepoort J Vet Res 1980, 47:137-142.

7. Van Wyk JA, Gerber HM, Alves RMR: Slight resistance to the residual effect of closantel in a field strain of Haemonchus contortus which showed an increased resistance after one selection in the laboratory. Onderstepoort J Vet Res 1982, 49:257-262.

8. Carmichael I, Visser R, Schneider D, Soil M: Haemonchus contortus resistance to ivermectin. J S Afr Vet 1987, 58:93. 
9. Van Wyk JA, Malan FS: Resistance of field strains of Haemonchus contortus to ivermectin, closantel, rafoxanide and the benzimidazoles in South Africa. Vet Rec 1988, 123:226-228.

10. Van Wyk JA, Van Schalkwyk PC, Gerber HM, Visser EL, Alves RMR, van Schalkwyk L: outh African field strains of Haemonchus contortus resistant to the levamisole/morantel group of anthelmintics. Onderstepoort J Vet Res 1989, 56:257-262.

11. Arundel JK: The chemotherapeutic arsenal. In Resistance in Nematodes to Anthelmintic Drugs. Edited by Anderson N, Waller PJ. Glebe: CSIRO Division of Animal Health, Australian Wool Corporation (Australian Wool Corporation Technical Publication); 1985:45-55.

12. Malan FS, van Wyk JA, Gerber HM, Alves RMR: First report of organophosphate resistance in a strain of Haemonchus contortus in the Republic of South Africa. S Afr J Sci 1990, 86:49-50.

13. Van Wyk JA, Malan FS, Randles JL: How long before resistance makes it impossible to control some field strains of Haemonchus contortus in South Africa with any of the modern anthelmintics? Vet Parasitol 1997, 70:111-122.

14. Anon: Report of the FAO expert consultation on helminth infections of livestock in developing countries. Rome: Rep. AGA-815, FAO; 1991.

15. LeJambre LF, Windon RG, Smith WD: Vaccination against Haemonchus contortus: Performance of native parasite gut membrane glycoproteins in Merino lambs grazing contaminated pasture. Vet Parasit 2008, 153:302-312.

16. Grønvold J, Wolstrup J, Larsen M, Henriksen SA, Nansen P: Biological control of Ostertagia ostertagi by feeding selected nematode-trapping fungi to calves. J Helminthol 1993, 67:31-36.

17. Waller PJ, Faeda M: The prospects of biological control of the free-living stages of nematode parasites of livestock. Int J Parasitol 1996, 26:915-925.

18. Githiori JB, Hoglund J, Waller PJ, Baker RL: Evaluation of anthelmintic properties of some plants used as livestock dewormers against Haemonchus contortus infections in sheep. Vet Parasit 2004, 129:245-253.

19. Adamu M, Oshadu OD, Ogbaje Cl: Anthelmintic efficacy of aqueous extract of Acanthus montanus leaf against strongylid nematodes of small ruminants. Afr J Tradit Complem 2010, 7:279-285.

20. Ademola IO, Eloff JN: In vitro anthelmintic activity of Combretum molle (R. Br. ex G. Don) (Combretaceae) against Haemonchus contortus ova and larvae. Vet Parasit 2010, 169:198-203.

21. Germishuizen G, Meyer NL: Plants of Southern Africa. An Annotated Check List. Strelitzia 14, iv. Pretoria: National Botanical Institute; 1999.

22. McGaw $\sqcup$, Eloff JN: Ethnoveterinary use of southern African plants and scientific evaluation of their medicinal properties. J Ethnopharmacol 2008, 119:559-574.

23. Bryant AT: Zulu Medicine and Medicine-Men. Cape Town: C. Struik; 1966

24. Watt JM, Breyer-Brandwijk MG: The Medicinal and Poisonous Plants of Southern and Eastern Africa. 2nd edition. London: Livingstone; 1962.

25. Hutchings A, Scott AH, Lewis G, Cunningham AB: Zulu Medicinal Plants: An Inventory. Pietermaritzburg: University of Natal Press; 1996.

26. Gerstner J: A preliminary checklist of Zulu names of plants with short notes. In Bantu Studies. 12th edition. Edited by George J, Liang MD, Drewes SE. South Africa: Phytochemical Research; 2001:215-236. S. Afr. J. Sci. 2001, 97: 93-105.

27. Bisset NG: The Asian species of Strychnos. Part III. The ethnobotany. Lloydia 1974, 37:62-107.

28. Jacot Guillarmod A: Flora of Lesotho. Lehr: Cramer; 1971.

29. Oliver-Bever B: Anti-infective activity of higher plants. In Medicinal Plants in Tropical West Africa. Cambridge University Press; 1986:123-190.

30. Doke CM, Vilakazi BW: Zulu-English Dictionary. 2nd edition. Johannesburg: Witwatersrand University Press; 1972.

31. Palmer E, Pitman N: Trees of Southern Africa, Volume 3. Cape Town Press: Balkema; 1972

32. Eloff JN: Which extractant should be used for the screening and isolation of antimicrobial components from plants? J Ethnopharmacol 1998, 60:1-8.

33. Kotze M, Eloff JN: Extraction of antibacterial compounds from Combretum microphyllum (Combretaceae). S Afr. J Bot 2002, 68:62-67.

34. Eloff JN, Famakin JO, Katerere DRP: Combretum woodii (Combretaceae) leaf extracts have high activity against Gram-negative and Gram-positive bacteria. Afr. J. Biotech 2005, 4:1161-1166.

35. Eloff JN: Quantifying the bioactivity of plant extracts during screening and bioassay-guided fractionation. Phytomedicine 2004, 11:370-371.
36. Coles GC, Bauer C, Borgsteede FHM, Geerts S, Klei TR, Taylor MA, Waller PJ: World Association for the Advancement of Veterinary Parasitology (W.A. A.V.P.) methods for the detection of anthelmintic resistance in nematodes of veterinary importance. Vet Parasit 1992, 44:35-44.

37. Hubert J, Kerboeuf D: A microlarval development assay for the detection of anthelmintic resistance in sheep nematodes. Vet Rec 1992, 130:442-446.

38. Ademola IO, Eloff JN: Anthelmintic activity of acetone extract and fractions of Vernonia amygdalina against Haemonchus contortus eggs and larvae. Trop Anim Health Pr. 2011, 43:521-527.

39. Mosmann T: Rapid colorimetric assay for cellular growth and survival: application to proliferation and cytotoxicity assays. J Immunol Methods 1983, 65:55-63.

40. MacGregor KJ, Embleton JK, Lacy JE, Perry EA, Solomon L, Seager H, Pouton CW: Influence of lipolysis on drug absorption from the gastrointestinal tract. Adv Drug Deliver Rev 1997, 25:33-46.

41. Domínguez SXA: Métodos de investigación fitoquímica. DF: Edited by Limusa SA México; 1979.

42. Tadesse D, Eguale T, Giday M, Mussa A: Ovicidal and larvicidal activity of crude extracts of Maesa lanceolata and Plectranthus punctatus against Haemonchus contortus. J Ethnopharmacol 2009, 2009(122):240-244.

43. Lukhoba CW, Simmonds SJ, Paton AJ: Plectranthus: a review of ethnobotanical uses. J Ethnopharmacol 2006, 103:1-24.

44. Price KR, Johnson IT, Fenwick GR: The chemistry and biological significance of saponins in foods and feedstuffs. CRC Crit Rev Food Sci Nutr 1987, 26:27-135.

45. Aremu AO, Fawole OA, Chukwujekwu JC, Light ME, Finnie JF, Van Staden J: In vitro antimicrobial, anthelmintic, cyclooxygenase-inhibitory activities and phytochemical analysis of Leucosidea sericea. J Ethnopharmacol 2010, 131:22-27.

46. Bosman AA, Combrinck S, Roux-van der Merwe BM, Botha R, McCrindle RI: Isolation of an anthelmintic compound from Leucosidea sericea. $S$ Afri J Bot 2004, 70:509-511.

47. Hoste H, Frank J, Spiridoula A, Thamsborg SM, Hoskin SO: The effects of tannin-rich plants on parasitic nematodes in ruminants. Trends Parasitol 2006, 6:253-261.

48. Villegas M, Vargas D, Msonthi JD, Marston A, Hostettmann K: Isolation of the antifungal compounds falcarindiol and sarisan from Heteromorpha trifoliata. Planta Med 1988, 54:36-37.

49. Bizimenyera ES, Githiori JB, Eloff JN, Swan GE: In vitro activity of Peltophorum africanum Sond. (Fabaceae) extracts on the egg hatching and larval development of the parasitic nematode Trichostrongylus colubriformis. Vet Parasit 2006, 142:336-343.

50. Eguale T, Tilahun G, Debella A, Feleke A, Makonne E: In vitro and in vivo anthelmintic activity of crude extracts of Coriandrum sativum against Haemonchus contortus. J Ethnopharmacol 2007, 110:428-433.

51. Maciel MV, Morais SM, Bevilaqua CM, Camurça-Vasconcelos AL, Costa CT, Castro CM: Ovicidal and larvicidal activity of Melia azedarach extracts on Haemonchus contortus. Vet Parasit 2006, 140:98-104.

52. Githiori JB, Hoglund J, Waller PJ: Ethnoveterinary plant preparations as livestock dewormers: practices, popular beliefs, pitfalls and prospects for the future. Anim Hith Res Rev 2005, 6:91-103.

53. Worku M, Franco R, Miller JH: Evaluation of the activity of plant extracts in Boer goats. Am J Anim Vet Sci 2009, 4:72-79.

54. Nchu F, Githiori JB, McGaw LJ, Eloff JN: Anthelmintic and cytotoxic activities of extracts of Markhamia obtusifolia Sprague (Bignoniaceae). Vet Parasit 2011, 183:184-188.

55. Vatta AF, Kandu-Lelo C, Ademola IO, Eloff JN: Direct anthelmintic effects of Cereus jamacaru (Cactaceae) on trichostrongylid nematodes of sheep: In vivo studies. Vet Parasit 2011, 180:279-286.

doi:10.1186/1746-6148-9-38

Cite this article as: Adamu et al:: Efficacy and toxicity of thirteen plant leaf acetone extracts used in ethnoveterinary medicine in South Africa on egg hatching and larval development of Haemonchus contortus. BMC Veterinary Research 2013 9:38. 